九州大学学術情報リポジトリ

Kyushu University Institutional Repository

\title{
A STUDY ON UNIFICATION OF WELDING CONSUMABLES IN CONSTRUCTION OF CHEMICAL CARGO TANKER MADE OF DUPLEX STAINLESS STEEL: EVALUATION OF STATIC STRENGTH OF WELDED JOINTT
}

Yotsuzuka, Takayuki

Shin Kurushima Dockyard Co., Ltd.

Endo, Yusuke

Shin Kurushima Dockyard Co., Ltd.

Ni ino, Eij i

Shin Kurushima Dockyard Co., Ltd.

Gotoh, Koji

Department of Marine Systems Engineering, Faculty of Engineering, Kyushu University

http://hdl. handle. net/2324/4753063

出版情報: Proceedings of the ASME 2019 38th International Conference on Ocean, Offshore and Arctic Engineering: OMAE2019, 2019-11-11. The American Society of Mechanical Engineers : ASME バージョン:

権利関係 : Copyright $\odot 2019$ by ASME 
OMAE2019-95818

\section{A STUDY ON UNIFICATION OF WELDING CONSUMABLES IN CONSTRUCTION OF CHEMICAL CARGO TANKER MADE OF DUPLEX STAINLESS STEEL -EVALUATION OF STATIC STRENGTH OF WELDED JOINT-}

\author{
Takayuki Yotsuzuka \\ Shin Kurushima Dockyard Co., Ltd. \\ 945-Kou, Shin-Machi, Onishi-Cho, \\ Imabari, Ehime \\ 799-2293, Japan \\ Tel: +81-92-802-3457 \\ Fax: +81-92-802-3368 \\ E-mail: TAKAYUKI_YOTSUZUKA@skdy.co.jp
}

Eiji Niino

Shin Kurushima Dockyard Co., Ltd.

945-Kou, Shin-Machi, Onishi-Cho, Imabari, Ehime

799-2293, Japan

Tel: +81-92-802-3464

Fax: +81-92-802-3368

Email: EIJI_NIINO@skdy.cO.jp

\author{
Yusuke Endo \\ Shin Kurushima Dockyard Co., Ltd. \\ 945-Kou, Shin-Machi, Onishi-Cho, \\ Imabari, Ehime \\ 799-2293, Japan \\ Tel: +81-92-802-3464 \\ Fax: +81-92-802-3368 \\ Email:YUSUKE_ENDO@skdy.cO.jp
}

\begin{abstract}
Austenitic stainless steels such as SUS 316 LN and austenitic stainless clad steel are used in cargo holds of chemical tankers owing to their corrosion resistance. Recently, the use of duplex stainless steels has been increasing, owing to their better strength and corrosion resistance and lower content of expensive $\mathrm{Ni}$, compared with those features of austenitic stainless steels. However, few duplex stainless clad steels have been approved by classification bodies. Furthermore, the application of duplex stainless steel is not yet mainstream as hull structural materials because a stable supply market has yet to be established. Therefore, when applying cladding steel to construction of chemical tankers, austenitic stainless clad steel is often used at present. The duplex stainless steel and the austenitic stainless clad steel are mixed at construction factories; hence, there is a risk of misuse of welding consumables. If misuse is suspected, it is not possible to judge the erroneous use from visual inspection after construction; therefore it is necessary to uniformly remove the weld and re-weld. However, if universal welding consumables were identified, this might avoid the problems of misuse and simplify the procurement of welding materials.
\end{abstract}

In this paper, we report on our studies to verify welding consumables for use in the hull structures, involving a mixture of duplex stainless steel and the austenitic stainless clad steel. The static strength of the welded joints is a particular focus of this study, from which we confirmed the validity and limitations of welding consumables.

\section{INTRODUCTION}

Chemical cargo tankers aim to safely carry corrosive liquid chemicals. Austenitic stainless steel and austenitic stainless clad steel such as SUS316LN are mainly used in cargo tanks owing to their corrosion resistance. Recently, there have been cases where duplex stainless steels are used, owing to their superior strength and corrosion resistance compared with those features of austenitic stainless steels. Additionally, duplex stainless steels have a low content of expensive $\mathrm{Ni}$. However, few products based on duplex stainless clad steel have been approved; thus, it is difficult to judge if these materials are suitable for application to hull structural elements. Furthermore, a stable supply system of these steel types is in the process of being established. For these reasons, duplex stainless steel is not yet widely used as a 
hull structural member. Therefore, austenitic stainless clad steel is currently used for construction of chemical tankers. Duplex stainless steel and austenitic stainless clad steel might be mixed at construction sites, raising the risk of inappropriate welding materials being used during construction. If misuse is suspected, it is not possible to judge the erroneous use from visual inspection after construction, so it is necessary to uniformly remove the weld and re-weld. If a universal welding material were established, this would avoid the problems of potential misuse and simplify procurement of welding materials.

In this paper, we report the results of our studies to verify universal welding materials for hull structures based on mixtures of duplex stainless steel and austenitic stainless clad steel.

\section{OUTLINE OF THE TEST}

Weld joints were produced by appropriately combining four types of base materials with two kinds of welding materials based on a hull structure composed of a mixture of duplex stainless steel and austenitic stainless clad steel. The soundness of the welded joints was evaluated by various mechanical tests based on the guideline requirements for welding procedure approval. Test specimens were made by an upward $\mathrm{CO}_{2}$ gasshield semi-automatic arc welding method according to the welding procedure standards of the shipyard, which some of the authors belong. The soundness of the welded joints was evaluated according to the "Rules for the Survey and Construction of Steel Ships Part M" [1] and "Guidelines on Welding of Duplex Stainless Steels" [2]. These guidelines specify that to preserve the strength and corrosion resistance of the welded joints made of duplex stainless steel, the heat input should be within the range of 5 to $35 \mathrm{~kJ} / \mathrm{cm}$. In this study, we consider a situation involving semiautomatic welded joints and investigate the influence of cases where the welding conditions fluctuated at the time of construction, with the heat input potentially exceeding $35 \mathrm{~kJ} / \mathrm{cm}$. The influence of excessive heat input on the soundness of the welded metal parts was also investigated.

\section{CHEMICAL COMPOSITION AND MECHANICAL PORPERTIES OF BASE METAL}

Table 1 shows the chemical composition and mechanical properties of the base metal used for the test. The names of the base metals are specified by the guidelines. KSUS329J3L is a duplex stainless steel, KSUS316LN is austenitic stainless steel, where the steel part of the stainless clad steel corresponds to SM490A.

\section{CHEMICAL COMPOSITION AND MECHANICAL PORPERTIES OF WELDING CONSUMABLES}

Table 2 shows the chemical composition and mechanical properties of the welded metals based on welding consumables, which were used for the testing. Welding consumables SF-DP8 [3] and DW-329AP [4] are certified as ClassNK standards KW
2209 [2] for welding of duplex stainless steel. Furthermore, DW309MoL [4] is are certified as ClassNK standards KW 309MoL [2].

TABLE1 CHEMCAL COMPOSITIONAND MECHANCAL PROPERTIES OF APPUED MATERIALS.

\begin{tabular}{|c|c|c|c|c|c|c|c|c|c|}
\hline & \multicolumn{9}{|c|}{ Chemical Composition (wt. \%) } \\
\hline Base metal & C & $\mathrm{Si}$ & $\mathrm{Mn}$ & $\mathrm{P}$ & $\mathrm{S}$ & $\mathrm{Ni}$ & $\mathrm{Cr}$ & Mo & $\mathrm{N}$ \\
\hline KSUS329J3L & 0.017 & 0.54 & 1.81 & 0.024 & 0.000 & 5.74 & 22.55 & 3.06 & 0.17 \\
\hline KSUS316LN & 0.013 & 0.71 & 0.66 & 0.029 & 0.000 & 10.75 & 18.13 & 2.85 & 0.17 \\
\hline $\begin{array}{l}\text { KSUS316LN } \\
\text {-CLAD(SUS) }\end{array}$ & 0.012 & 0.45 & 1.22 & 0.025 & 0.001 & 10.76 & 17.59 & 2.88 & 0.15 \\
\hline $\begin{array}{l}\text { KSUS316LN } \\
\text {-CLAD(MS) }\end{array}$ & 0.160 & 0.19 & 0.64 & 0.014 & 0.006 & 0.01 & 0.02 & 0.00 & 0.00 \\
\hline \multirow[t]{2}{*}{ SM490A } & 0.160 & 0.35 & 1.30 & 0.008 & 0.001 & \multirow[t]{5}{*}{0.01} & \multirow[t]{5}{*}{0.02} & \multirow[t]{5}{*}{0.00} & \multirow[t]{5}{*}{0.01} \\
\hline & \multirow{2}{*}{\multicolumn{2}{|c|}{\begin{tabular}{|l|}
$0.2 \% \mathrm{YS}$ \\
$\left(\mathrm{N} / \mathrm{mm}^{2}\right)$
\end{tabular}}} & \multirow{2}{*}{\begin{tabular}{|c|} 
TS \\
$\left(\mathrm{N} / \mathrm{mm}^{2}\right)$
\end{tabular}} & \multirow{2}{*}{\begin{tabular}{|l} 
EL \\
$(\%)$
\end{tabular}} & & & & & \\
\hline Base metal & & & & & & & & & \\
\hline KSUS329J3L & 580 & & 769 & 34 & & & & & \\
\hline KSUS316LN & 374 & & 678 & 49 & & & & & \\
\hline
\end{tabular}

TABLE 2 CHEMCAL COMPOSITION OF WEDING CONSUMABLES.

\begin{tabular}{|c|c|c|c|c|c|c|c|c|c|}
\hline & \multicolumn{9}{|c|}{ Chemical Composition (wt. \%) } \\
\hline Welding wire & $\mathrm{C}$ & $\mathrm{Si}$ & $\mathrm{Mn}$ & $P$ & $S$ & $\mathrm{Ni}$ & $\mathrm{Cr}$ & Mo & $\mathrm{N}$ \\
\hline SF-DP8 & 0.040 & 0.44 & \begin{tabular}{l|l|}
4 & 1.14
\end{tabular} & 0.019 & 0.006 & 8.80 & 23.50 & 3.10 & 0.13 \\
\hline DW-329AP & 0.024 & 0.63 & \begin{tabular}{|l|l|}
3 & 0.88
\end{tabular} & 0.020 & 0.005 & 9.11 & 22.99 & 3.40 & 0.13 \\
\hline DW-309MoL & 0.023 & 0.72 & \begin{tabular}{|l|l|}
2 & 0.61 \\
\end{tabular} & 0.019 & 0.002 & \multirow[t]{6}{*}{12.61} & \multirow[t]{6}{*}{22.28} & \multirow[t]{3}{*}{2.70} & 0.03 \\
\hline & \multirow{2}{*}{\multicolumn{2}{|c|}{$\begin{array}{l}0.2 \% \mathrm{YS} \\
\left(\mathrm{N} / \mathrm{mm}^{2}\right)\end{array}$}} & \multirow{2}{*}{$\begin{array}{c}\mathrm{TS} \\
\left(\mathrm{N} / \mathrm{mm}^{2}\right)\end{array}$} & \multirow{2}{*}{\begin{tabular}{|c|} 
EL \\
$(\%)$
\end{tabular}} & & & & & \\
\hline Welding wire & & & & & & & & & \\
\hline SF-DP8 & 640 & & 806 & 24 & & & & & \\
\hline DW-329AP & 638 & & 819 & 29 & & & & & \\
\hline DW-309MoL & 521 & & 690 & 30 & & & & & \\
\hline
\end{tabular}

\section{COMBINATIONS OF BASE METAL AND WELDING CONSUMABLES}

Table 3 shows combinations of four types of base materials and combinations of welding consumables, which were evaluated in this research.

TABLE 3 MATRIX OF APPUED TO THE BASE METAL COMBINATION THAT PRODUCED TOTHE WE DED JOINT.

\begin{tabular}{|c|c|c|c|c|}
\hline Base Metal & KSUS329J3L & KSUS316LN & $\begin{array}{c}\text { KSUS316LN } \\
\text {-CLAD }\end{array}$ & SM490A \\
\hline KSUS329J3L & $\begin{array}{c}\text { SF-DP8 } \\
\text { DW-329AP } \\
\text { DW-309MoL }\end{array}$ & - & DW-309MoL & $\begin{array}{c}\text { DW-329AP } \\
\text { DW-309MoL }\end{array}$ \\
\hline KSUS316LN & & & DW-329AP & DW-329AP \\
\hline $\begin{array}{c}\text { KSUS316LN } \\
\text {-CLAD }\end{array}$ & & & DW-329AP & DW-329AP \\
\hline SM490A & & & & - \\
\hline
\end{tabular}

The red letters in Table 3 corresponds to a combination of steel materials not recommended for use in Classification Rules. The purpose of this research is to confirm the soundness of the welded joint against the combination of the red letters, if we can confirm the soundness of these series of combinations, it is possible to unify welding consumables. 
The reason why the test was not conducted using the welding material of KW2209 in the combination of KSUS 329J3L and KSUS316LN-CLAD is because the result of the combination of KSUS329J3L and SM490A is substituted.

\section{GROOVE SHAPE AND DIMENSIONS}

Figure 1 shows groove shape and dimensions of test specimens. It is standard to make test specimens as the joint gap set to $6 \mathrm{~mm}$, When intentionally setting welding heat input amount to $35 \mathrm{~kJ} / \mathrm{cm}$ or more, a joint was made with the groove gap set to $12 \mathrm{~mm}$.

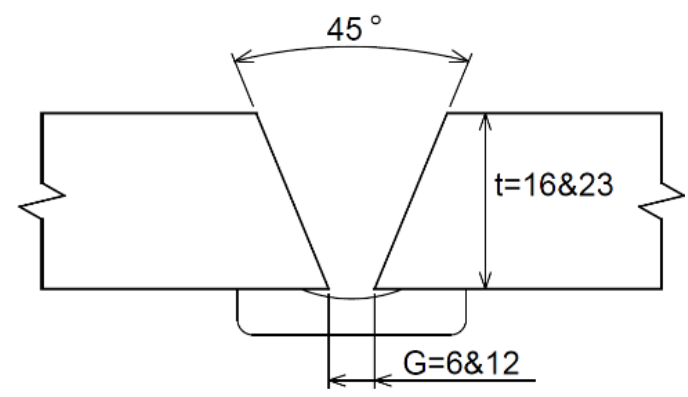

RGURE 1 GROOVE SHAPE AND DIMENSIONS USED.

\section{WELDING CONDITION}

Table 4 shows examples of welding condition when tested. The inter-pass temperature was set to $150^{\circ} \mathrm{C}$ or less.

\section{MECHANICAL TEST FOR TEST SPECIMENS}

The mechanical tests were carried out in accordance with the rules of ClassNK's "Rules for the Survey and Construction of Steel Ships", Part 2, Part 3 of K, Part 2, Part M of Chapter 4. Table 5 shows the types of mechanical tests and the number of test pieces.

The ferrite content measurement on the weld metal surface was carried out according to the "Guidelines on Welding of Duplex Stainless Steels" [2] chapter 4. In addition, the microscopic structure observation of the specimen cross section was also conducted for the purpose of whether the structure of the weld metal part is sound or not. Fig. 2 shows the test points of ferrite content measurement and microscopic structure observation.
TABLE 4 EXAMPLES OF WEDING CONDITION.

\begin{tabular}{|c|c|c|c|c|c|}
\hline $\begin{array}{l}\text { Base Metal : KSUS3 } \\
\text { Welding Wire : SF-D } \\
\text { Welding direction : V }\end{array}$ & $\begin{array}{r}\text { JS329 } \\
\text { Bac }\end{array}$ & $\begin{array}{l}\mathrm{J} 3 \mathrm{~L} \quad \mathrm{P} \\
\text { king Mat }\end{array}$ & $\begin{array}{l}\text { ate Thich } \\
\text { rial : SB }\end{array}$ & $\begin{array}{l}\text { ess : } 23 n \\
41\end{array}$ & \\
\hline $\mathrm{Gap}=6 \mathrm{~mm}$ & Pass & $\begin{array}{l}\text { Current } \\
\text { (A) }\end{array}$ & $\begin{array}{l}\text { Voltage } \\
\text { (V) }\end{array}$ & $\begin{array}{c}\text { Speed } \\
\text { (cm/min) }\end{array}$ & $\begin{array}{l}\text { Heat imput } \\
(\mathrm{kJ} / \mathrm{cm})\end{array}$ \\
\hline & 1 & 140 & 23 & 7.7 & 25.1 \\
\hline & 2 & 150 & 24 & 9.4 & 23.0 \\
\hline & 3 & 150 & 24 & 9.1 & 23.7 \\
\hline & 4 & 150 & 24 & 10.0 & 21.6 \\
\hline & 5 & 150 & 24 & 7.4 & 29.2 \\
\hline
\end{tabular}

Base Metal : KSUS329J3L×KSUS329J3L Plate Thickness : 23mm Welding Wire : SF-DP8 1.2Ф Backing Material : SB-41 Welding direction : Vertical-up

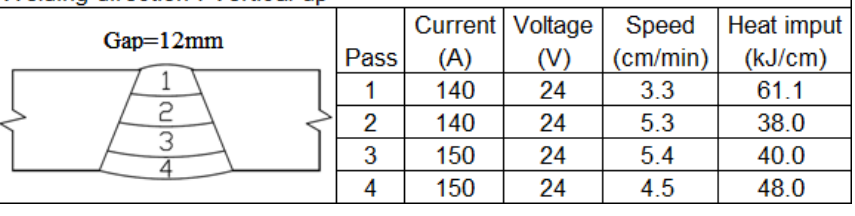

Base Metal : KSUS329J3L×SM490A Plate Thickness : 16mm Welding Wire : DW-329AP 1.2Ф Backing Material : FBB-3T Welding direction : Vertical-up

\begin{tabular}{|c|c|c|c|c|c|c|}
\hline $\mathrm{Gap}=6 \mathrm{~mm}$ & & Pass & $\begin{array}{c}\text { Current } \\
\text { (A) }\end{array}$ & $\begin{array}{c}\text { Voltage } \\
\text { (V) }\end{array}$ & $\begin{array}{l}\text { Speed } \\
(\mathrm{cm} / \mathrm{min})\end{array}$ & $\begin{array}{l}\text { Heat imput } \\
(\mathrm{kJ} / \mathrm{cm})\end{array}$ \\
\hline & \multirow{4}{*}{ MS } & 1 & 200 & 24 & 9.0 & 33.1 \\
\hline SUS & & 2 & 200 & 24 & 17.0 & 16.9 \\
\hline & & 3 & 160 & 25 & 12.0 & 20.5 \\
\hline & & 4 & 160 & 25 & 12.0 & 19.8 \\
\hline
\end{tabular}

Base Metal : KSUS316LN-CLAD×SM490A Plate Thickness : $16 \mathrm{~mm}$ Welding Wire : DW-329AP 1.2థ Backing Material : FBB-3T Welding direction : Vertical-up

\begin{tabular}{|c|c|c|c|c|c|c|}
\hline \multicolumn{2}{|l|}{$\mathrm{Gap}=6 \mathrm{~mm}$} & Pass & $\begin{array}{c}\text { Current } \\
\text { (A) }\end{array}$ & $\begin{array}{c}\text { Voltage } \\
\text { (V) }\end{array}$ & $\begin{array}{l}\text { Speed } \\
(\mathrm{cm} / \mathrm{min})\end{array}$ & $\begin{array}{l}\text { Heat imput } \\
(\mathrm{kJ} / \mathrm{cm})\end{array}$ \\
\hline & \multirow{4}{*}{ MS } & 1 & 160 & 25 & 9.0 & 26.1 \\
\hline $\mathrm{CL}$ & & 2 & 160 & 25 & 17.0 & 14.0 \\
\hline & & 3 & 160 & 25 & 13.0 & 18.1 \\
\hline & & 4 & 160 & 25 & 13.0 & 18.4 \\
\hline
\end{tabular}

Base Metal : KSUS316LN-CLAD×KSUS316LN-CLAD Plate Thickness: $16 \mathrm{~mm}$ Welding Wire : DW-100 1.2Ф (1st,2nd path) Backing Material : FBB-3T DW-329AP $1.2 \Phi(3$ rd, 4 th path) Welding direction : Vertical-up

\begin{tabular}{|c|c|c|c|c|c|c|}
\hline \multicolumn{2}{|c|}{$\mathrm{Gap}=6 \mathrm{~mm}$} & Pass & \begin{tabular}{|c} 
Current \\
(A)
\end{tabular} & $\begin{array}{c}\text { Voltage } \\
\text { (V) }\end{array}$ & $\begin{array}{l}\text { Speed } \\
\text { (cm/min) }\end{array}$ & $\begin{array}{l}\text { Heat imput } \\
(\mathrm{kJ} / \mathrm{cm})\end{array}$ \\
\hline \multirow{4}{*}{$4 \mathrm{CLAD}$} & \multirow{4}{*}{ CLAD } & 1 & 200 & 24 & 11.0 & 26.5 \\
\hline & & 2 & 200 & 24 & 17.0 & 16.5 \\
\hline & & 3 & 160 & 25 & 13.0 & 18.9 \\
\hline & & 4 & 160 & 25 & 15.0 & 16.2 \\
\hline
\end{tabular}

Base Metal : KSUS316LN-CLAD $\times$ KSUS316LN-CLAD Plate Thickness: $16 \mathrm{~mm}$ Welding Wire : DW-329AP 1.2Ф Backing Material : FBB-3T Welding direction : Vertical-up

\begin{tabular}{|c|c|c|c|c|c|}
\hline $\mathrm{Gap}=6 \mathrm{~mm}$ & Pass & $\begin{array}{c}\text { Current } \\
\text { (A) }\end{array}$ & $\begin{array}{c}\text { Voltage } \\
\text { (V) }\end{array}$ & $\begin{array}{l}\text { Speed } \\
\text { (cm/min) }\end{array}$ & $\begin{array}{c}\text { Heat imput } \\
(\mathrm{kJ} / \mathrm{cm})\end{array}$ \\
\hline \multirow{4}{*}{4 CLAD) } & 1 & 160 & 25 & 12.0 & 19.9 \\
\hline & 2 & 160 & 25 & 17.0 & 13.8 \\
\hline & 3 & 160 & 25 & 16.0 & 14.6 \\
\hline & 4 & 160 & 25 & 15.0 & 15.7 \\
\hline
\end{tabular}


TABLE 5 MECHANCAL TEST CONDITIONS.

\begin{tabular}{|c|c|c|}
\hline Kind of test & $\begin{array}{l}\text { Number of } \\
\text { specimen }\end{array}$ & Remarks \\
\hline Tensile test & 1 & \\
\hline Face bend test & 1 & \\
\hline Root bend test & 1 & \\
\hline Charpy impact test & $\begin{array}{c}3 \\
(1 \text { set })\end{array}$ & $\begin{array}{l}V \text { notch position is centre of } \\
\text { weld metal }\end{array}$ \\
\hline Hardness test & 1 & Vickers hardness. \\
\hline $\begin{array}{l}\text { Macro-structure } \\
\text { inspection }\end{array}$ & 1 & \\
\hline $\begin{array}{l}\text { Chemical } \\
\text { composition } \\
\text { measurement }\end{array}$ & 1 & \\
\hline $\begin{array}{l}\text { Ferrite content } \\
\text { measurement }\end{array}$ & 1 & $\begin{array}{l}3 \text { points } \times 5 \text { times on the face } \\
\text { of weld metal }\end{array}$ \\
\hline $\begin{array}{l}\text { Micro-structure } \\
\text { inspection }\end{array}$ & 1 & $\begin{array}{l}2 \text { points on the weld metal and } \\
2 \text { points on the fusion line }\end{array}$ \\
\hline
\end{tabular}

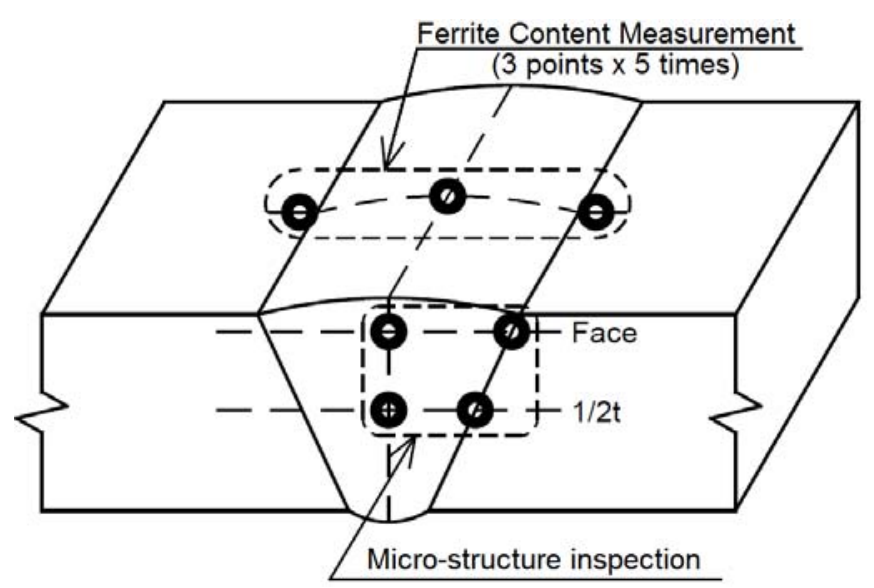

HGURE 2 TEST POINTS OF FERRTE CONTENT MEASURENENT ANDMCROSCOPIC STRUCTURE OBSERVATION.

\section{TENSILE TEST RESULTS}

(1) Tensile test results of KSUS329J3L - KSUS329J3L welded joint

Figure 3 shows tensile test results of welding joints between KSUS329J3L. Two kinds of welding consumables are used for Duplex Stainless Steels for which ClassNK certified as standard name KW2209 and for Austenitic Stainless Steels certified as $\mathrm{KW} 309 \mathrm{MoL}$, and welded joints were made in a range where the welding heat input was smaller than the upper guideline value of $35 \mathrm{~kJ} / \mathrm{cm}$ and beyond. The white symbol in Fig. 3 corresponds to the case where the heat input amount at the time of welding the joint is less than $35 \mathrm{~kJ} / \mathrm{cm}$, the black symbol corresponds to the case where the heat input amount at the time of joint welding exceeds $35 \mathrm{~kJ} / \mathrm{cm}$.

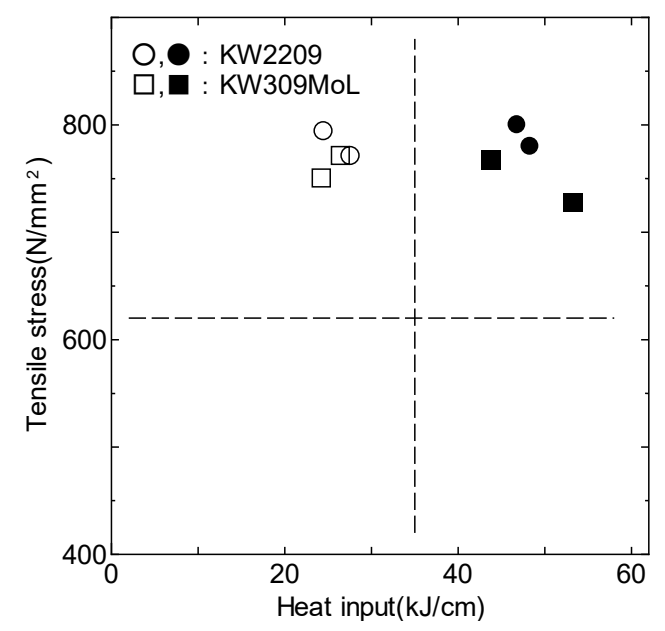

RGURE 3 TENSILE TEST RESULTS OF KSUS329J3L- KSUS329J3L WEDED JOINT.

It was confirmed that even when any of the welding consumables were used and even when the welding heat input exceeds the guideline upper limit value of $35 \mathrm{~kJ} / \mathrm{cm}$, the tensile strength exceeds $620 \mathrm{~N} / \mathrm{mm}^{2}$, which is the specification required value of the Duplex Stainless Steel material. However, all four specimens using KW2209 fractured in the base metal, whereas all four specimens using KW309MoL fractured at the weld metal.

(2) Tensile test results of various combinations of base metals

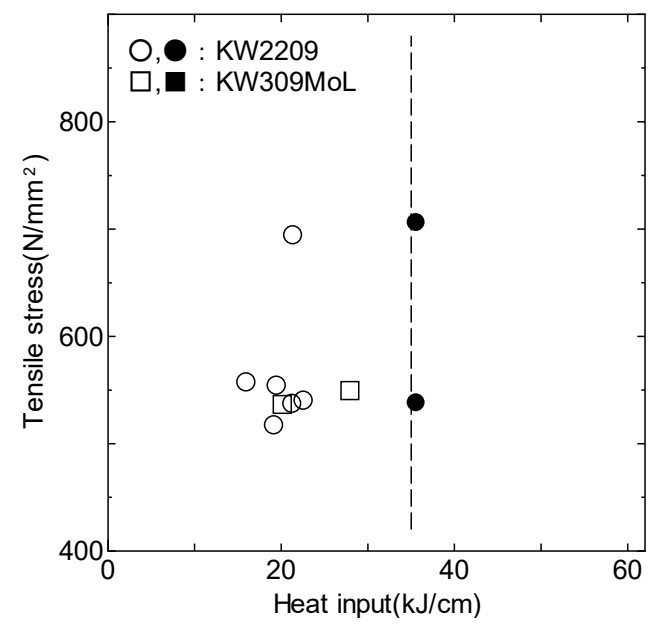

RGURE4 TENSILE TEST RESULTS OF VARIOUS COMBINATION OF BASE METALS.

Figure 4 shows tensile test results of various combinations of base metal. The combination of base metals were KSUS329J3L - SM490A, KSUS316LN Clad - KSUS316LN Clad , KSUS316LN Clad- SM490A , KSUS316LN- 
KSUS316LN , KSUS316LN-SM490A , KSUS329J3LKSUS316LN Clad, and KW2209 and KW309MoL were used for welding consumables.

In any of the specimens, the value exceeding the tensile strength standard value of the lower of the materials constituting the joint, and the fracture position in all joints was the base metal part.

\section{FACE BEND TEST RESULTS}

No defects such as cracks were found in the welded joint in any of the test specimens. As an example, Fig.5 shows a Face Bend test piece of a specimen whose welding heat input was higher than $35 \mathrm{~kJ} / \mathrm{cm}$ by using a joint of KSUS329J3L and using SF - DP 8 as a welding consumables.

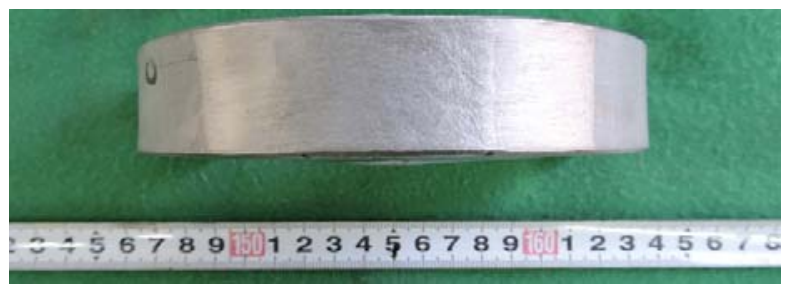

RG5 TEST RESULTS OF FACE BEND.

\section{IMPACT TEST RESULTS}

(1) Impact test results of KSUS329J3L-KSUS329J3L welded joint

Figure 6 shows position of notch for impact test specimens.

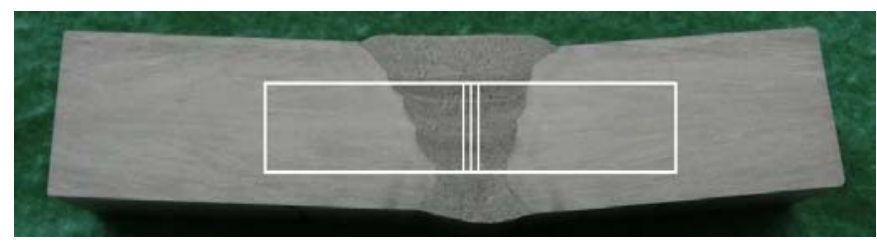

FGURE 6 POSITION OF NOTCHFOR IMPACT TEST SPECIMENS.

Figure 7 shows Impact test results of KSUS329J3L KSUS329J3L welded joint. Even when any welding consumables are used or even when welding heat input exceeds the guideline upper limit value of $35 \mathrm{~kJ} / \mathrm{cm}$, the target minimum average absorbed energy value $27 \mathrm{~J}$ (test temperature $-20^{\circ} \mathrm{C}$ ) is satisfied was confirmed.

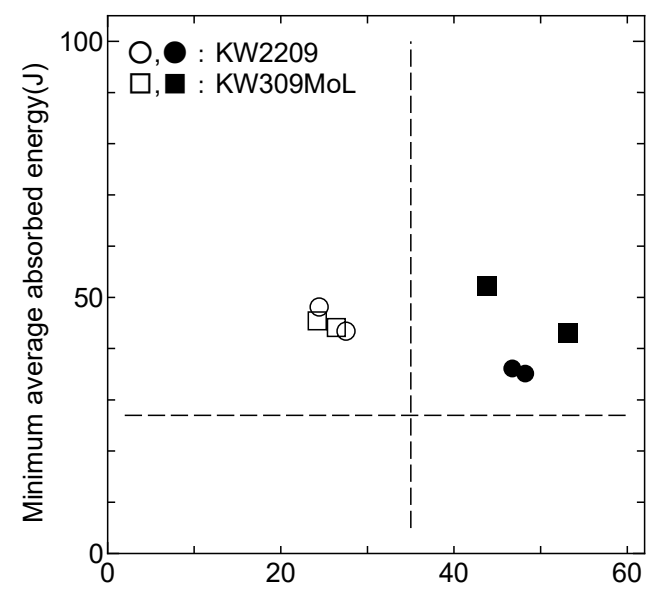

RGURE 7 CHARPY ABSORBED in ENERGY OF KSUS329J3LKSUS329J3L WEDED JOINT FABRICATED UNDER MULTIPLE HEAT IMPUT CONDITIONS.

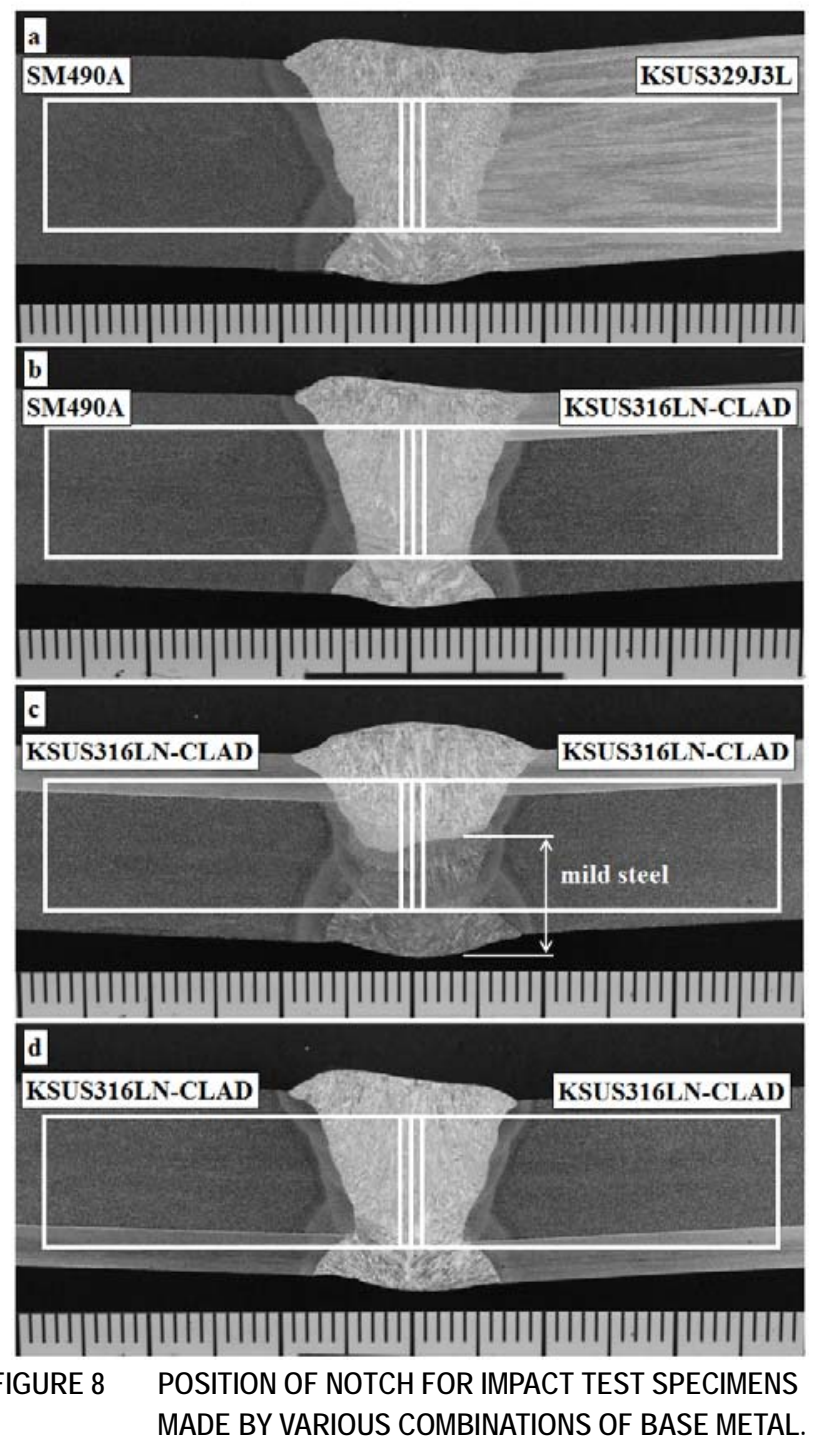




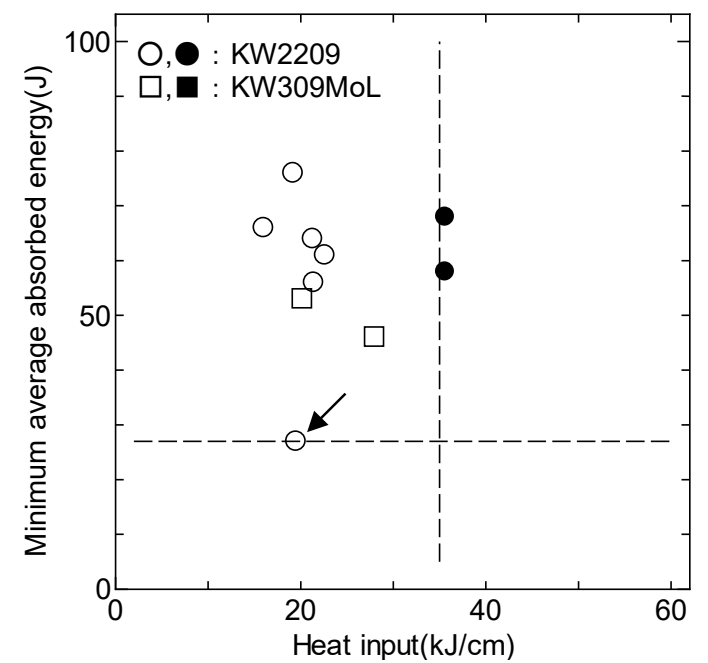

HGURE 9 CHARPY ABSORBEDENERGY OF VARIOUS COMBINATIONBASE METALS.

(2) Impact test results of various combinations of base metals

Figure 8 shows position of notch for impact test specimens made by various combinations of base metal.

Figure 9 shows Impact test results of various combinations of base metals. The combination of base metals were KSUS329J3L - SM490A, KSUS316LN Clad - KSUS316LN Clad , KSUS316LN Clad- SM490A , KSUS316LNKSUS316LN , KSUS316LN-SM490A , KSUS329J3LKSUS316LN Clad, and KW2209 and KW309MoL were used for welding consumables. Only one specimen shown as an arrow in Fig. 9 resulted in lower value. Because specimen welded 1st and 2 nd pass by using welding consumable for mild steel (see Figure 8-c), so half of the test specimen consists of mild steel.

Even when any welding consumables are used or even when welding heat input exceeds the guideline upper limit value of $35 \mathrm{~kJ} / \mathrm{cm}$, the target minimum average absorbed energy value $27 \mathrm{~J}$ (test temperature $-20^{\circ} \mathrm{C}$ ) is satisfied was confirmed.

\section{VICKERS HARDNESS TEST RESULTS}

(1) Vickers Hardness test results of KSUS329J3L KSUS329J3L welded joint

Figure 10 shows Vickers Hardness test results of KSUS 329J3L - KSUS329J3L welded joint.

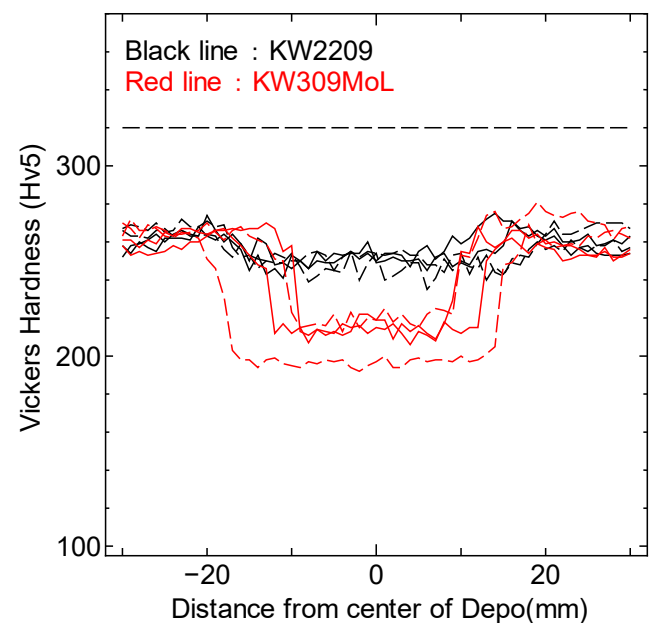

\section{RGURE10 MEASURED VCKERS HARDNESS DISTRIBUTION OF KSUS329J3L- KSUS329J3L WEDED JOINT.}

It was confirmed that the measurement of Vickers Hardness including the HAZ part satisfies the standard value $\mathrm{Hv} \leq 320$ of KSUS329J3L prescribed in "Rules for the Survey and Construction of Steel Ships" Chapter 3 of Part K [3]. In addition, it was also confirmed that the weld metal part of the specimen welded using KW309MoL became an under-match joint softened more than the HAZ part, base metal.

(2) Vickers Hardness test results of various combinations of base metals

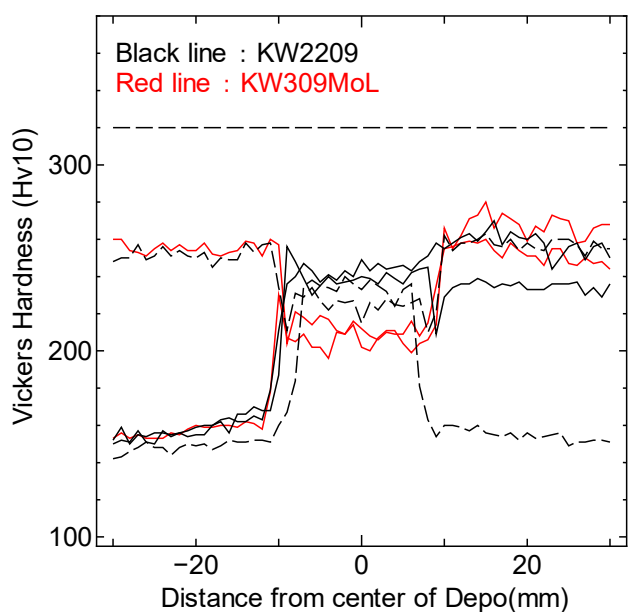

RGURE 11 MEASURED VCKERS HARDNESS DISTRIBUTION OF VARIOUS COMBINATIONS OF BASE METALS

Figure 11 shows Vickers Hardness test results of various combinations of base metals. It was also confirmed that the 
measurement of Vickers Hardness including the HAZ part satisfies the standard value $\mathrm{Hv} \leq 320$ of KSUS329J3L prescribed in "Rules for the Survey and Construction of Steel Ships" Chapter 3 of Part K [3]. In addition, it was also confirmed that the weld metal part of the specimen welded using KW309MoL became an under-match joint softened more than the HAZ part, base metal.

\section{MACROSCOPIC OBSERVATION RESULTS}

No abnormality was confirmed in any of the test pieces. As an example, Fig. 12 shows macroscopic observation of cross section of KSUS329J3L - KSUS329J3L welded joint with a weld heat input higher than $35 \mathrm{~kJ} / \mathrm{cm}$ by using SF-DP 8 as a welding consumables.

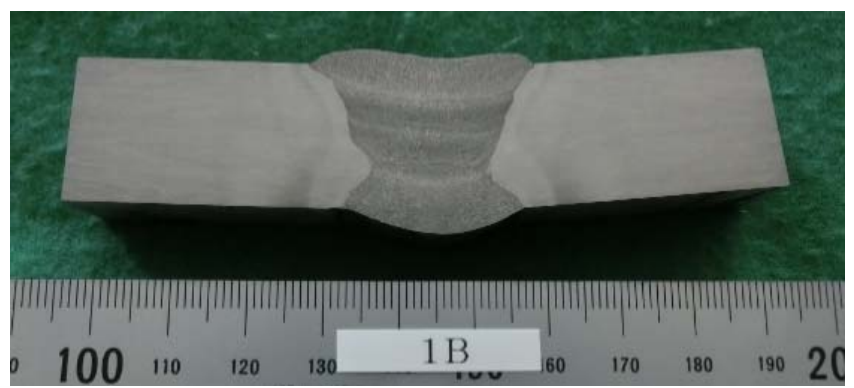

RGURE 12 MCROSCOPIC OBSERVATION OF CROSS SECTION OF KSUS329J3L- KSUS329J3L WEDED JOINT.

\section{CHEMICAL COMPOSITION OF WELD METAL}

We measured Chemical composition of weld metal. The test conditions were KSUS329J3L - KSUS329J3L welded joints, three kinds of welding materials were used, two kinds of KW2209 (SF-DP8 and DW-329AP) and one kind of KW309MoL (DW-309Mol), welding heat input was $35 \mathrm{~kJ} / \mathrm{cm}$, which is smaller and larger. Table 5 shows results.

\section{TABLF 5 CHEMCAL COMPOSITION OF WE DMETAL}

\begin{tabular}{|c|c|c|c|c|c|c|c|c|c|c|}
\hline $\begin{array}{c}\text { Heat } \\
\text { Input }\end{array}$ & $\begin{array}{c}\text { Name of } \\
\text { welding wire }\end{array}$ & $\mathrm{C}$ & $\mathrm{Si}$ & $\mathrm{Mn}$ & $\mathrm{P}$ & $\mathrm{S}$ & $\mathrm{Ni}$ & $\mathrm{Cr}$ & $\mathrm{Mo}$ & $\mathrm{N}$ \\
\hline 24.5 & SF-DP8 & 0.031 & 0.60 & 1.51 & 0.018 & 0.004 & 7.72 & 22.84 & 3.10 & 0.13 \\
\hline 27.6 & DW-329AP & 0.023 & 0.62 & 0.65 & 0.022 & 0.003 & 8.80 & 22.86 & 3.53 & 0.14 \\
\hline 26.5 & DW-309MoL & 0.031 & 0.62 & 0.71 & 0.020 & 0.003 & 11.77 & 22.32 & 2.84 & 0.04 \\
\hline 46.8 & SF-DP8 & 0.026 & 0.62 & 1.45 & 0.018 & 0.004 & 7.94 & 22.95 & 3.14 & 0.13 \\
\hline 48.3 & DW-329AP & 0.024 & 0.60 & 0.63 & 0.022 & 0.003 & 8.84 & 22.65 & 3.54 & 0.14 \\
\hline 53.2 & DW-309MoL & 0.026 & 0.70 & 0.64 & 0.019 & 0.002 & 12.16 & 22.17 & 2.78 & 0.04 \\
\hline
\end{tabular}

It was confirmed from the measurement results that the test piece welded using KW309MoL had higher Ni content than the test piece welded using KW2209. Since Ni tends to make the structure of the metal into an austenitic, the test piece welded using KW309MoL may decrease the ferrite content.

\section{FERRITE CONTENT MEASUREMENT RESULTS}

In the guideline, it is stipulated that the ferrite content in the welded part of Duplex Stainless Steel is measured and the result falls within the range of 30 to $70 \%$. This is to ensure that the welded joint and the HAZ area are Duplex Stainless Steel as well as the base metal. For this reason, the ferrite content measurement was carried out for the KSUS329J3LKSUS329J3L welded joint by the method prescribed in the guideline. Three kinds of welding materials were used, two kinds of KW2209 (SF-DP8 and DW-329AP) and one kind of KW309MoL (DW-309Mol), welding heat input was $35 \mathrm{~kJ} / \mathrm{cm}$, which is smaller and larger. Table 5 shows results. Fig. 13 shows the results of ferrite content in the central part of the weld metal on the surface of the specimen.

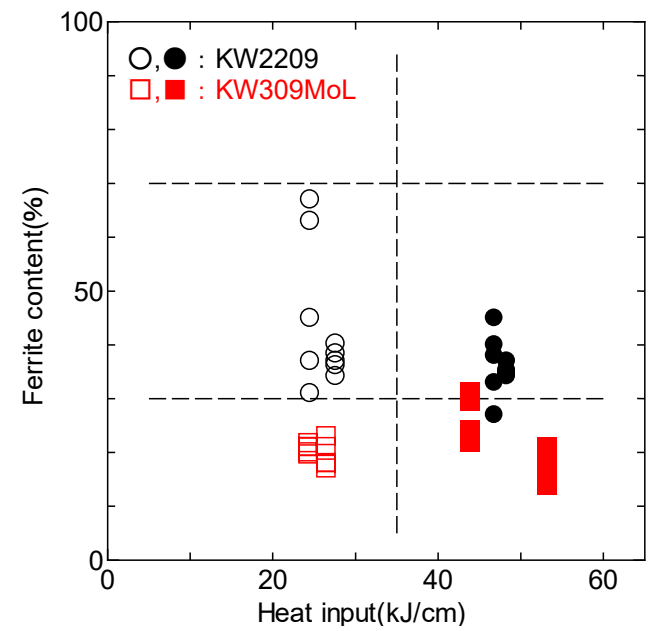

FGURE 13 MEASURED FERRTIE CONTENT OF WED METAL ON THE WEDSURFACE

When evaluated according to the guidelines ${ }^{2)}$, it was confirmed that there was no problem concerning the ferrite content in the combination of the base metal and the welding consumables of the joints to be evaluated in this research because of the measured maximum value is within the range of 30 to $70 \%$. However, the ferrite content in the weld metal part of the welded joint using $\mathrm{KW} 309 \mathrm{MoL}$ was about $30 \%$ or less. This is presumably because weld metal is composed of nearly austenitic structure because $\mathrm{Ni}$ contained in the welding consumables is larger than KW2209.

Next, the result of ferrite content on the surface of HAZ area of the specimen surface is shown in Fig.14. In all the measurements, although the ferrite content was small, but the maximum measured value was satisfied with the required value for guidelines. 


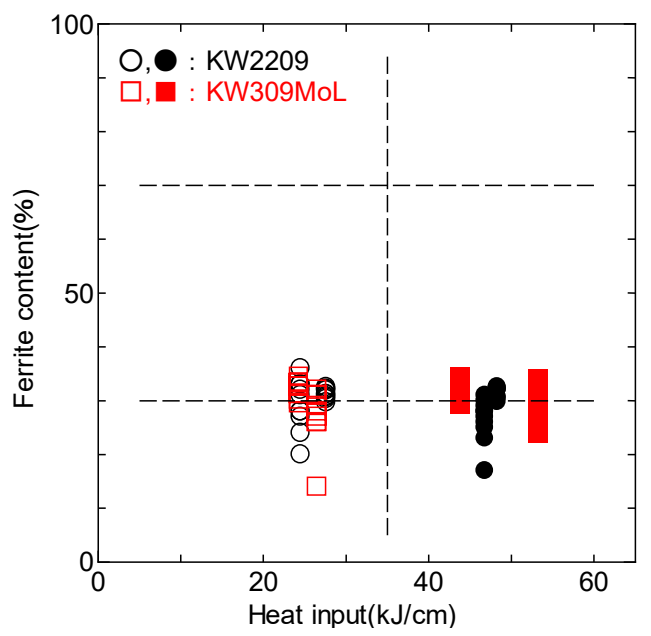

RGURE 14 MEASURED FERRTIE CONIENT OF HAZ ON THE WED SURFACE

\section{MICROSCOPIC OBSERVATION RESULTS}

In order to confirm the ratio of austenite structure and ferrite structure in the weld metal and HAZ area, the Microscopic observation in the vicinity of weld toe was carried out for the KSUS329J3L - KSUS329J3L weld joint made by using the two kinds of welding consumables, one is the KW2209 and the other is KW309MoL. Results are shown in Fig. 15.

No harmful intermetallic compounds were observed in any of the test pieces. But it was found that ferrite structure decreased when welding consumables for Austenitic Stainless Steel was used.

\section{CONCLUSIONS}

The soundness was evaluated mainly on static strength in order to unify the welding consumables in ship building with a mixture of Duplex Stainless Steel and Austenitic Stainless Clad Steel with welding joints were made by combining various base metals and welding consumables.

As a result, the test piece welded using the welding consumables of KW2209 to the KSUS329J3L-KSUS329J3L, KSUS329J3L - KSUS316LN Clad steel or Mild Steel satisfies the performance required by ClassNK in all the tests confirmed. Also, even when the welding heat input was set to $35 \mathrm{~kJ} / \mathrm{cm}$ or more, there were no signs that the performance of the weld metal deteriorated. However, it was also confirmed that the performance of the test piece welded to KSUS329J3L using KW309MoL did not satisfy the performance in some tests.

Future work is to verify the fatigue strength of the joint.

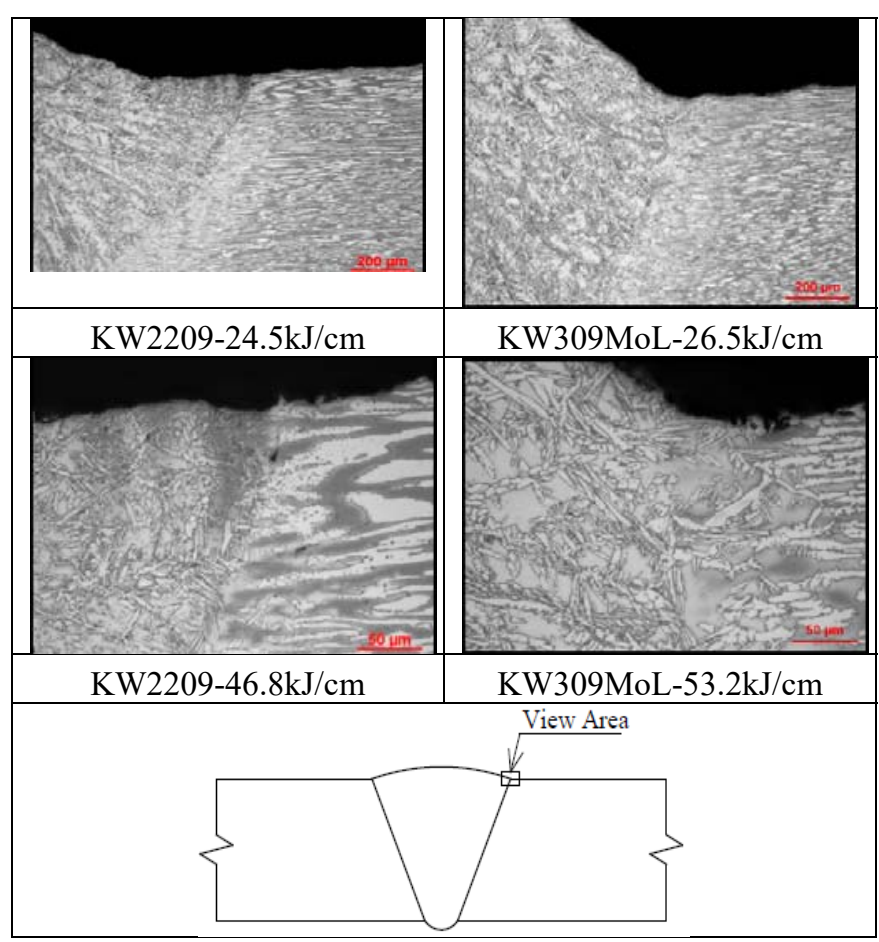

RGURE 15 MCROSCOPICOBSERVATIONINTHE VCINTY OF WED TOE OF KSUS329J3L- KSUS329J3L WE DED JOINT.

\section{ACKNOWLEDGEMENT}

I would like to show my greatest appreciation to $\mathrm{Mr}$. Takeshi Hashimoto of Nippon Steel \& Sumikin Stainless Steel Co., Ltd. and Mr. Ken Yamashita of Kobe Steel Co., Ltd. for cooperating in this study.

\section{REFERENCES}

[1] Nippon Kaiji Kyokai (ClassNK) : Rules for the Survey and Construction of Steel Ships Part M-Welding, 2018

[2] Nippon Kaiji Kyokai (ClassNK) : Guidelines on Welding of Duplex Stainless Steels, 2014.

[3] Nippon Kaiji Kyokai (ClassNK) : Rules for the Survey and Construction of Steel Ships Part K-Materials, 2018. 